\title{
Structure and Diversity of Tree Species at the College of Forestry and Fisheries, University of Agriculture Makurdi, Benue State, Nigeria
}

\author{
Amonum, J.I., Jonathan, B.A., Japheth, H.D \\ Department of Forest Production and Products, College of Forestry and Fisheries, University of Agriculture \\ Makurdi, Nigeria
}

*Corresponding Authors: Amonum, J.I., Department of Forest Production and Products, College of Forestry and Fisheries, University of Agriculture Makurdi, Nigeria

\begin{abstract}
This study was carried out to assess tree species diversity and distribution within the vegetation area at the College of Forestry and Fisheries, University of Agriculture Makurdi in Nigeria. Trees are important component of vegetation because of their economic value to mankind. There is high pressure on forest estates, especially in the tropics; due to high demand on forest economic resources as a result of geometric increase of human population in the region. The study area covered with vegetation was estimated to be 106,875 $\mathrm{m}^{2}$. About 21,375 $\mathrm{m}^{2}$ of the site was sampled and divided into plots, sizes of $50 \times 50 \mathrm{~m}$, thereby given a total of 8 plots i.e. $20 \%$ of the total study area. The plots were laid $25 \mathrm{~m}$ apart, perpendicular to a road track within the study area. In each sample plot, data collected during the study included: the number of individual species; tree height, stem diameter $\geq 10 \mathrm{~cm}$. Stem diameters and total height were measured using diameter tape and Haga altimeter, respectively. A total number of 177 trees were enumerated within the sampled area. The results of the study showed 32 genera belonging to 20 families were present. Families of Combretaceae had 6 frequency and Vebenaceae, Rutaceae, Anacardiaceae, Leguminosae were dominant with 3 frequencies each; Daniellia oliverii recorded the highest frequency of 29. Some economic tree species (such as: Prosopis africana, Pakia biglobosa, Khaya senegalenses and Burkia africana) were still available in appreciable numbers. Farming and grazing were some of the major problems in the study area. There is serious need for restriction and proper monitoring of this study area. This measure will prevent some of the economic tree species from becoming threatened in the study area.
\end{abstract}

Keywords: Conservation; Economic trees; Forest; Species diversity; Tree species.

\section{INTRODUCTION}

Tree composition and distribution is very helpful in understanding the status of forest stands, regeneration, and diversity for conservation purposes. The structure of forest estates largely depends on the ecological characteristics of sites, species diversity and regeneration status of tree species. Quantitative information on composition, distribution, or abundance of trees species is of key importance to understanding the status (composition and structure) of a forest estate; also for decision-making, planning and implementation of conservation strategy of the forest estate(s).

Species richness and diversity of tree species are fundamental to total forest biodiversity, because trees provide resources and habitat for almost all wildlife species (Malik 2014; Sushma et al 2016). Changes on flora and fauna species of natural ecosystems have in the second half of 20th century become a global problem due to intensive anthropogenic activities. In order to manage disturbed and undisturbed stands and to understand the provision of non-timber ecosystem services, it is imperative to describe patterns of species composition (Neelo et al., 2015).

Tropical forests are disappearing at alarming rates worldwide, reducing annually by about $4 \%$ of their current area. Component of vegetation must therefore be constantly monitored and managed in order to direct succession processes towards maintaining species and habitat diversity (Attua and Pabi 2013). Abundance or diversity of tree species is an important aspect in forest ecosystem and is also basic to forest biodiversity. Forest stand structure is a key element in understanding forest ecosystems and also an important element of stand biodiversity (Ozcelik et al, 2008)

Savanna occupy one eight (1/8) of the global land surface and support a proportion of the world's human population and majority of its rangeland and livestock (Scholars and Archer 1997). Many 
explanations for the persistence of tree-grass mixtures in savannas have been advanced thus far, but perceptions differ on whether the suite of interactions that characterize savanna system results in mix of trees and grasses that is 'Stable' or 'unstable' (Scholes and Archer 1997). Broadly, proposed explanations for the persistence of trees and grasses in savannas fall into two categories: those that emphasize the fundamental role of competitive interactions in fostering coexistence (hereafter composition-based models), and those that focus on the limiting roles of demographic bottlenecks to tree establishment and persistence in savannas (demographic-bottleneck models).

The significant pressures on forest reserves through anthropogenic activities such as over exploitation of forest resources, grazing in forest estates and conversion of forest areas to other forms of land uses such as residential, schools, industries, road construction among others and unstable climate conditions. The overall impacts are reduction, fragmentation and impaired natural ecosystem functions. Today there is an urgent need for conservation measures and adoption of sustainable land use methods throughout Africa to avoid further degradation of the natural resources. According to Lykke (1998) scientific long-term data on vegetation changes are generally lacking for most savanna areas. In Nigeria, for instance there is limited accurate data on flora composition.

This study is aimed at assessing tree species diversity and distribution within the forested area at the College of Forestry and Fisheries, University of Agriculture Makurdi. Knowledge on tree species diversity and distribution would serve as baseline information to know the status of the tree species in the study area; which is basic in understanding regeneration processes, such as tree growth, tree mortality, under-storey development, and the spread of disturbances (Isango,2007; Francisco et al., 2017).

\section{Materials AND Method}

\subsection{Study Area}

This study was carried out within the vegetation area at the College of Forestry and Fisheries, North Core, University of Agriculture Makurdi, Nigeria. The study area lies between Longitude $8^{\circ} 35^{\prime}$ and $9^{\circ} \mathrm{E}$ and Latitude $7^{\circ} 45^{\prime}$ and $7^{\circ} 52^{\prime} \mathrm{N}$, in the southern guinea ecological zone. The area is characterized by two distinct seasons, the wet and dry season respectively. The wet season is between April to October while the dry season is between November to March. Rain fall distribution is bimodal with maximum rainfall occurring between June and September. Mean annual rain fall is between $1000 \mathrm{~mm}$ $1500 \mathrm{~mm}$, mean annual temperature is $30^{\circ} \mathrm{C}$, and relative humidity is about $80 \%$ but decreases in the early months of dry season (Ikyaabga, 2008).

\subsection{Sampling Procedure}

The study area covered with vegetation within the College of Forestry and Fisheries of the University of Agriculture, Makurdi was estimated to be about 106,875 $\mathrm{m}^{2}$. About 21,375 $\mathrm{m}^{2}$ of the site was sampled and divided into plots, sizes of $50 \times 50 \mathrm{~m}$, thereby given a total of 8 plots which was $20 \%$ of the total study area. The plots were laid $25 \mathrm{~m}$ apart, perpendicular to a road track within the study area. Within each sample plot, data collected during the study includes the number of individual species; tree height, stem diameter $\geq 10 \mathrm{~cm}$. Stem diameters and total height were measured using diameter tape and Haga altimeter respectively.

\subsection{Data Analysis}

\subsubsection{Forest Structure}

The structure of the natural forest investigated was analyzed through the distribution of stem diameter and height of tree species in the study area. The total height and diameter of the tree species measured within the 8 temporary sample plots were classed and frequency of each class was determined.

\subsubsection{Shannon-Weiner Index of Diversity $\left(H^{\prime}\right)$}

Species diversity within the study area were analyzed using the diversity index of Shannon and Weaver (1949), the index varies depending on the number of species present. It is higher when there are more species, indicating greater diversity. Shannon-Weiner Index of diversity ( $\left.\mathrm{H}^{\prime}\right)$ was calculated following Kent and Coker (1992) and Magurran (2004):

$$
H^{\prime}=-\sum_{i=1}^{s} p_{i} \ln p_{i}
$$

Where: $S=$ total number of species; $p i=$ relative frequency of species; $L n=$ natural logarithm. 


\subsubsection{Simpson's Index}

The Simpson's index of diversity:

$D=1-\left(\frac{\sum n(n-1)}{N(N-1)}\right)$

Where: $\mathrm{n}$ is the total number of organisms of a particular species and $\mathrm{N}$ is the total number of individual of all species.

\subsubsection{Species Evenness Index}

The Pielou evenness index varies between 0 and 1. It is 0 when there is a phenomenon of dominance and 1 when the distribution of individuals among species is homogenous. Pielou evenness index was also calculated, using the stated formula as (Adekunle et al., 2013):

$H_{S}=\frac{H^{\prime}}{\ln S}$

Where: $S$ is the total number of species and $\mathrm{H}^{\prime}=$ diversity index. $\mathrm{In}=$ natural logarithm, $\mathrm{H}^{\prime}=$ Species evenness

\subsubsection{Species Richness}

Species richness was computed using the procedure outlined by Margalef (1951) and followed by Speller berg (1991) and Magurran (2004) as used by Oluwatos in and Jimoh (2016):

$\mathrm{D}=\frac{S}{\sqrt{n}}$

Where: $\mathrm{D}=$ species richness index (Margalef index), $\mathrm{S}=$ the total number of species and $\mathrm{N}=$ the total number of individuals.

\subsubsection{Statistical Analyses}

The data collected were subjected to statistical analysis using PAST version 2.14 and MS Excel 2017 version, while species were identified by field assistants who has the knowledge of taxonomy on tree species identification.

\section{RESULTS}

\section{Statistics for Tree Growth Variables within the Vegetation Area at the College of Forestry and Fisheries, University of Agriculture Makurdi}

Table1 shows the statistics of tree growth variables in the study area. Based on the results, the mean diameter at base was $28.68 \mathrm{~cm}$ with standard deviation of 12.78. The maximum and minimum diameters at base were recorded as $73.80 \mathrm{~cm}$ and $10.20 \mathrm{~cm}$, respectively. The mean diameter at breast height was recorded as $23.13 \mathrm{~cm}$ with a standard deviation of 11.24 . The minimum dbh of $10.80 \mathrm{~cm}$ was recorded and the maximum dbh of $62.60 \mathrm{~cm}$ in the study area. Mean total height of 9.08 meters and a standard deviation of 3.02. Minimum total height of $2.00 \mathrm{~m}$ and maximum of $19.00 \mathrm{~m}$ were recorded in the study area.

Table1. Summary Statistics of Tree Growth Variables in the Study Area

\begin{tabular}{|l|l|l|l|l|l|}
\hline Tree Variable & \multicolumn{5}{|c|}{ Descriptive Statistics } \\
\hline & N & Mean & SD & Minimum & Maximum \\
\hline $\mathrm{Db}(\mathrm{cm})$ & 177 & 28.68 & 12.78 & 10.20 & 73.80 \\
\hline $\mathrm{Dbh}(\mathrm{cm})$ & 177 & 23.13 & 11.24 & 10.80 & 62.60 \\
\hline $\mathrm{Ht}(\mathrm{m})$ & 177 & 9.08 & 3.02 & 2.00 & 19.00 \\
\hline
\end{tabular}

Where: $S D=$ standard deviation, $D b=$ Diameter at base, Dbh = Diameter at breast height $(\mathrm{cm}), \mathrm{Ht}=$ Total height $(m)$ and $N=$ Total number of trees measured

\subsection{Forest Structure in the Study Area}

Figure 1 shows the Dbh classes $(\mathrm{cm})$ distribution of the tree in the study area; based on this finding, the dbh distribution ranged from 10.00 to $>60.00 \mathrm{~cm}$. One hundred and forty $(140)$ trees belong to $\mathrm{dbh}$ class of 10.00 to $30.00 \mathrm{~cm}$, followed by 30.10 to $40.00 \mathrm{~cm}$ class interval which had 24 trees, seven (7) trees were under the dbh class distribution between 50.10 to $60.00 \mathrm{~m}$ while dbh class distribution $>60.00 \mathrm{~cm}$ had 3 trees. This gave rise to a reverse ' $J$-shape' shape diameter distribution in the study area (Figure 1). 


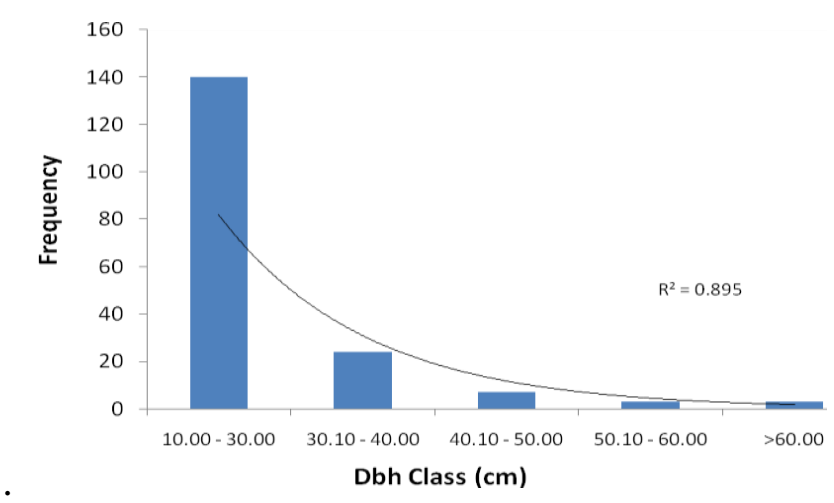

Figure1. Distribution of Trees in different Dbh classes (cm) in the Study Area

Figure 2 shows the distribution of trees in different height classes in the study area. The total height of tree species in the study area ranged from $<5.00$ to $19.00 \mathrm{~m}$. One hundred and eleven (111) trees belonged to the height class of 5.00 to $10.00 \mathrm{~m}$ followed by class interval of 10.10 to $15.00 \mathrm{~m}$ which had 50 trees. Ten trees had total height between 15.00 to $19.00 \mathrm{~m}$ as observed during this study.

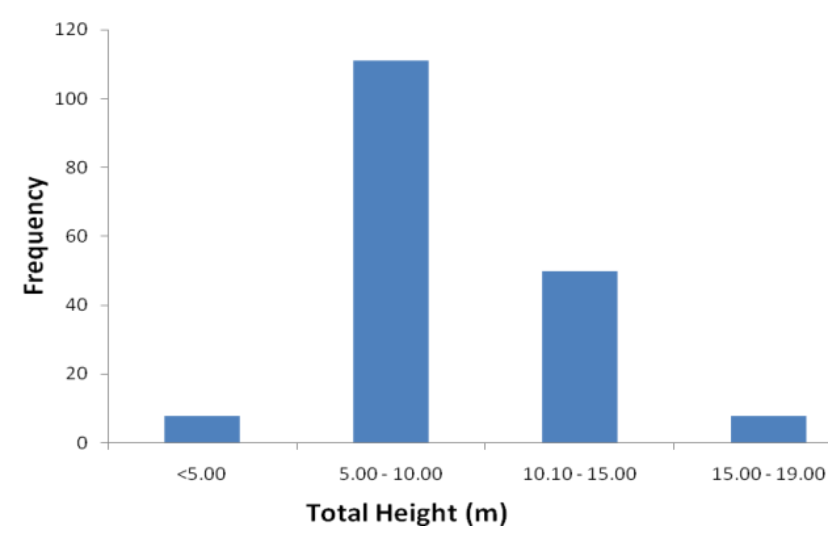

Figure2. Distribution of Trees in different Height Classes in the Study Area

\subsection{Tree Species Diversity and Abundance}

Tree species diversity and abundance in the study area are presented in Table 2 . Based on the result, a total number of one hundred and seventy seven (177) individual trees were recorded with; 39 tree species, thirty two (32) genera from 20 families were identified in the study area. Shannon-weiner index of diversity $\left(\mathrm{H}^{\prime}\right)$, Pielou's evenness index $(\mathrm{E})$, Menhinic index of species Richness and Simpson's index of diversity had a value of $3.21,0.88,2.93$, and 0.95 respectively, as obtained during this study.

Table2. Tree Species Diversity and Abundance in the Study Area

\begin{tabular}{|l|l|}
\hline Indices & Values \\
\hline Number of individual & 177 \\
\hline Number of tree species & 39 \\
\hline Number of genera & 32 \\
\hline Number of families & 20 \\
\hline Shannon-Weiner Index of diversity (H') & 3.21 \\
\hline Pielou's Evenness Index (E) & 0.88 \\
\hline Menhinick index of Species Richness & 2.93 \\
\hline Simpson's index of diversity & 0.95 \\
\hline
\end{tabular}

\subsection{Tree Species Composition in the Study Area}

Based on this finding, Figure 4 shows tree species distribution among families in the study area. Family of Combretaceae and Fabaceae had six (6) species each while Anacardiaceae, Leguminoseae and Meliaceae had four (4) species each and Euphorbiaceae, Rubiaceae and Stercullaceae had three (3) species each while Mimosoideae, Moraceae and Verbenaceae had two (2) species each, respectively. 
Structure and Diversity of Tree Species at the College of Forestry and Fisheries, University of Agriculture Makurdi, Benue State, Nigeria

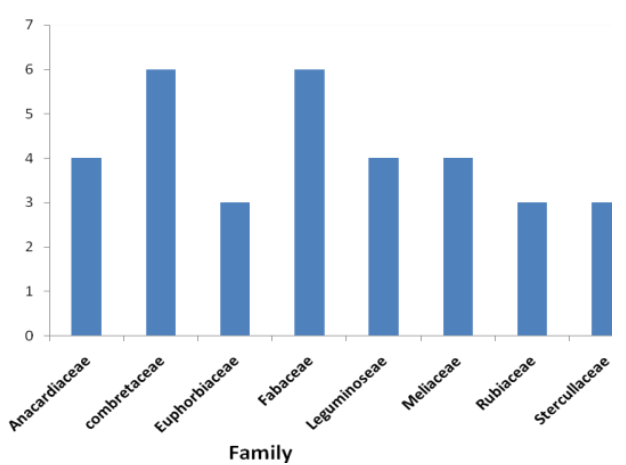

Figure4. Tree Species Distribution among Families in the Study Area

Table 3 shows the tree species, frequency and species local names in the study area. Thirty nine (39) tree species were identified, these include: Detorium microcarpum and Strychnos Spinoza, which had $5.07 \%$ and $4.15 \%$ respectively. Acacia nilotica, Crossopteryx febrifuga, Burkea africana and Vitex doniana had $2.76 \%$ each. Parinari curitellifolia and Prosopis africana had $2.30 \%$ and $3.69 \%$ respectively. Vitex doniana had the highest frequency of fifteen (15) which was recorded as the most dominant tree species in the study area.

Table3. Frequency Distribution of Tree Species in the Study Area

\begin{tabular}{|c|c|c|c|c|c|}
\hline $\mathbf{S} / \mathbf{N}$ & Species & Origin & Family & Frequency & Percentage \\
\hline 1 & Acacia nilotica & Indigenous & Leguminosae & 6 & 3.39 \\
\hline 2 & Anacardium occidentale & - & Anacardiaceae & 1 & 0.56 \\
\hline 3 & Anogeissus specatus & Indigenous & Combretaceae & 4 & 2.26 \\
\hline 4 & Annona senegalalensis & Indigenous & Annonaceae & 2 & 1.13 \\
\hline 5 & Anogeissus leocarpus & Indigenous & Combretaceae & 3 & 1.69 \\
\hline 6 & Azadirachta indica & Indigenous & Mellaceae & 1 & 0.56 \\
\hline 7 & Bridellia ferruginea & Indigenous & Euphorblaceae & 6 & 3.39 \\
\hline 8 & Bridellia oliverii & - & Euphorblaceae & 1 & 0.56 \\
\hline 9 & Burkea africana & Indigenous & Fabaceae & 6 & 3.39 \\
\hline 10 & Combretum molle & Indigenous & Combretaceae & 5 & 2.82 \\
\hline 11 & Combretum nigricans & Indigenous & Combretaceae & 11 & 6.21 \\
\hline 12 & Crossopteryx febrifuga & Indigenous & Rubiaceae & 1 & 0.56 \\
\hline 13 & Daniellia oliverii & Indigenous & Leguminosea & 29 & 16.38 \\
\hline 14 & Detorium microcarpum & Indigenous & Leguminosae & 1 & 0.56 \\
\hline 15 & Ficus exasperate & Indigenous & Moraceae & 1 & 0.56 \\
\hline 16 & Ficus Sur & - & Moraceae & 1 & 0.56 \\
\hline 17 & Gmelina arborea & Indigenous & Verbenaceae & 2 & 1.13 \\
\hline 18 & Khaya senegalensis & Indigenous & Meliaceae & 3 & 1.69 \\
\hline 19 & Lannea schimferi & Indigenous & Anacardiaceae & 2 & 1.13 \\
\hline 20 & Lannea acida & Exotic & Anacardiaceae & 2 & 1.13 \\
\hline 21 & Lannea nigritana & - & Anacardiaceae & 5 & 2.82 \\
\hline 22 & Lophira lanceolata & Indigenous & Ochanceae & 2 & 1.13 \\
\hline 23 & Maranttes polyandra & Indigenous & Chrysobalanceae & 3 & 1.69 \\
\hline 24 & Parinari curitelliflolia & Indigenous & - & 1 & 0.56 \\
\hline 25 & Parkia biglobosa & Indigenous & Mimosaceae & 8 & 4.52 \\
\hline 26 & Pericopsis laxiflora & Indigenous & Papilionoidae & 1 & 0.56 \\
\hline 27 & Piliostigma thonningii & Indigenous & Ceasalpinioideae & 1 & 0.56 \\
\hline 28 & Prosopis Africana & Indigenous & Mimosoidea & 13 & 7.34 \\
\hline 29 & Pseudocedrela kotschy & Indigenous & Meliaceae & 7 & 3.95 \\
\hline 30 & Pycnanthus euronasius & Indigenous & Myristiceareae & 1 & 0.56 \\
\hline 31 & Sacorcephalus latifolies & Indigenous & Rubeceae & 9 & 5.08 \\
\hline 32 & Sterculia setigera & Indigenous & Stercllaceae & 4 & 2.26 \\
\hline 33 & Stereospermum kunthianum & Indigenous & Bignoniaceae & 3 & 1.69 \\
\hline 34 & Strychnos spinosa & Indigenous & Loganiaceae & 2 & 1.13 \\
\hline 35 & Terminalia avicennioides & Indigenous & Combretaceae & 6 & 3.39 \\
\hline 36 & Terminalia scimperiam & Indigenous & Combretaceae & 1 & 0.56 \\
\hline 37 & Vitellaria paradoxa & Indigenous & Sapotaceae & 4 & 2.26 \\
\hline 38 & Vitex doniana & Indigenous & Verbenaceae & 15 & 8.47 \\
\hline 39 & Zanthoxylum zanthoxyloides & Indigenous & Rutaceae & 3 & 1.69 \\
\hline
\end{tabular}




\section{DISCUSSION}

Most of the species found in the area were species that can with stand fire (i.e. fire resistance) as observed during this finding. The structure of tree species in the study area was similar to that of Akure Forest Reserve in Ondo State (Adekunle et al., 2013) and Oluwa Forest Reserve, Ondo State (Ogana et al 2015) both in Southwest Nigeria.

According to Adekunle et al. (2013), 222 tree stands were found to be in the lower Dbh class of 10 $20 \mathrm{~cm}$, followed by $21-30 \mathrm{~cm}$ which had 78 tree stands with 2 tree stands in Dbh class of $>81 \mathrm{~cm}$. Hence, he reported that the reverse 'J-shape' diameter distribution indicated healthy recruitment potentials; the lower class diameter tree stands could develop into mature trees and replace the old ones in the future if proper conservation efforts are sustained. Thus, this structure is typical of a natural forest (Ogana and Gorgoso-Varela, 2015).

The tree height distribution result, implies that more numbers of trees found within the middle height stratum $(5$ to $15 \mathrm{~m})$ and only few trees in the lower $(<5 \mathrm{~m})$ and upper $(>15 \mathrm{~m})$ height stratum. This might be as a result of competition for sunlight, which gave rise to only few trees having dominant heights. This result followed a similar height trend with that of Akure Forest Reserve in Ondo, Nigeria as reported by Adekunle et al. (2013).

A total number of one hundred and seventy seven individual trees were recorded; thirty nine (39) tree species were identified in the study area and were distributed in twenty (20) families, thirty two (32) genera. Leguminosaea, Combretdecrease, Verbenaceae, Mimosaceae, were the most dominating families. This shows that the study area is rich in plants species. A high number of tree species increases the number of ecological niches for fauna (Wunderle, 1997) and under storey flora (Kanowski et al., 2003). Thus, the presence of numerous tree species on a stand not only aid conservation of more trees but other organisms as well.

When compared result of this study to a similar study by Oluwatosin and Jimoh (2016), Onigambari Forest Reserve, Nigeria had higher number of families (54) tree species; while, Muazu (2010), who reported four families in Kuyambana Forest Reserve, Zamfara state, Nigeria. He reported the dominance of Caesalpinaceae, Mimosaceae and Combretaceae families.

The law (prohibition of tree felling) protecting this study area could be the major reason that reduces disturbances from human activities such as fuel wood collection, charcoal production, timber exploitation. This was also observed and reported by Hooper et al., (2005) and Spiegel berger et al., (2006). Land use changes are responsible for decrease in species richness and diversity.

This finding is similar to the finding of Ikyaagba (2008) and Maohuama (2006), who noted that human activities have greater impacts on tree species distribution and composition. Some important economic tree species like: Prosopis africana, parkia biglobosa, Khaya senegalensis and Burkea africana were still available in appreciable numbers. This implies that conservation measures put in place have preserved many of these tree species in the study area. These measures will prevent some of the economic tree species from becoming threaten or extinct in the study area.

The species diversity assessed with the Shannon-Weiner $\left(\mathrm{H}^{\prime}\right)$ index in the study site was found to be 3.21. This result indicates high tree species diversity as stated by Magurran (2004) that a low $\mathrm{H}^{\prime}$ value generally suggests a site with few species and a few dominant species, while a high $\mathrm{H}^{\prime}$ value suggests considerably more species. This result is similar to that reported by Aigbe and Omokhua (2015) who obtained 3.80 for the Rainforest of Oban Forest Reserve, Nigeria and 3.74 reported by Adekunle et al., (2013) for Akure Forest Reserve, Nigeria. A high value (0.95) of Simpson's (1-D) diversity index result obtained in this study confirmed the high species diversity in the study area. The species diversity indices and evenness index revealed presence of high tree diversity and even representation of species in the studied forest compared to other forests (Adekunle et al., 2013; Aigbe and Omokhua, 2015; Oluwatosin and Jimoh, 2016). 


\section{CONCLUSION}

Based on the result of this finding in the study area, a total of 39 tree species, 32 genera and 20 families were enumerated in the study area. The results also revealed that Combretaceae had the highest number of tree species (6) while Anacardiaceae had four (4) species. There is the need to make proper implementation of conservation and sustainable management strategies. If small parcels of land are left undisturbed for period of time several forest tree species, shrubs or herbaceous plants will emerge and grow within the lost forest and bare land. From the results of this study, it is recommended that all agricultural activities should be control. Department of Forestry should design programmes that will create awareness on the part of the people to see the need of protecting tree species in the entire forested and bare land.

\section{REFERENCES}

[1] Athua, E.M and Pabi, O. (2013) Tree species composition, richness and diversity in the northern forest savanna ecotone of Ghana J. App. Biosc. 67.5437-5448.

[2] Francisco M. P. Gonçalves, Rasmus Revermann, Amândio L. Gomes, Marcos P. M. Aidar, Manfred Finckh, and Norbert Juergens (2017): Tree Species Diversity and Composition of Miombo Woodlands in South-Central Angola: A Chrono sequence of Forest Recovery after Shifting Cultivation; Hindawi International Journal of Forestry Research Volume 2017, Article ID 6202093, 13 pages https://doi.org/10.1155/2017/6202093

[3] Hopper, D.U.; Chapin, F.S.; Ewel, J. J.; Hector, A.; Inchausti,p.; Lavorel, S.; Lawton, J.H.; Lodge, D. M.; Loreau, M.; Naeem, S.; Schmid, B.; Setala, H.; Symtad, A.J.; Vandermeer, J. and Wardle, D. A. (2005); Effect of Biodiversity on Ecosystem Functioning: A consensus of Current Knowledge. Ecological Monographs, 75(1):3-35

[4] Ikyaagba, E.T. (2008). Plant biodiversity and Ethno botanical potential of University of Agriculture Makurdi wildlife park and Ikwe Game Reserves, Igbo Benue State Nigeria; (Unpublished thesis in the Department of Forest Resources Management University of Ibadan, Ibadan Nigeria 1-123pp).

[5] Isango,J.A. (2007). Stand structure and tree species composition of Tanzania miombo wood lands: A case study from miombo woodlands of community based forest management in Iringa District, Working Papers of the Finnish Forest Research Institute, No.50: 43-56.

[6] Kanowski J, Catterall CP, Wardell-Johnson GW, Proctor, H. and Reis, T. (2003): Development of forest structure on cleared rainforest land in eastern Australia under different styles of reforestation. Forest Ecology Management; 183: 265-80.

[7] Kent, M. and Coker, P. (1992): Vegetation description and analysis: a practical approach. Belhaven press London: 363pp

[8] Lykke, A.M. (1998): Assessment of species composition change in savanna vegetation by means of woody plants' size class distributions and local information. Biodiversity and Conservation 7: 1261-1275

[9] Magurran, A.E. (2004): Measuring Biological Diversity. Blackwell Publishing, Boston

[10] Malik ZA, Hussain A, Iqbal K. (2014). Species richness and diversity along the disturbance gradient in Kedarnath Wildlife Sanctuary and its adjoining areas in Garhwal Himalaya, India. International Journal of Current Research 6:10918e 10926.

[11] Maohua, M.A. (2006): Plant species diversity of Buffer zone in Agricultural landscape.in search of Determinants from local to Regional http;//ethesis Helsinki. Fi/juikasut/Mao/sboil/vk/ma / plantspe.pdf.

[12] Neelo, J.; D. Teketay, K. Kashe, and W. Masamba (2015): Stand structure, diversity and regeneration status of woody species in open and ex closed dry woodlands sites around molapo farming areas of the Okavango Delta, Northeastern Botswana; Open Journal of Forestry, 5(4): 313-328.

[13] Ogana, F. N., and Gorgoso-Varela, J. J. (2015): Comparison of estimation Methods for fitting Weibull distribution to the Natural Stand of Oluwa Forest Reserve, Ondo State, Nigeria. Journal of Research in Forestry, Wildlife and Environment, 7(2), 81-90.

[14] Ogana, F. N., Osho, J. S. A., and Gorgoso-Varela, J. J. (2015): Comparison of Beta, Gamma Weibull Distributions for characterising tree diameter in Oluwa Forest Reserve, Ondo State, Nigeria, Journal of Natural Sciences Research, .5(4), 28-36.

[15] Oluwatosin, B and Jimoh, S.O. (2016): Pattern of plant species diversity in a dry forest ecosystem of Nigeria, Journal of Forestry Research and Management, 13: 31-47

[16] Ozcelik,R.; Gul,A.U.; Merganič,J.\& Merganičová,K. (2008): Tree species diversity and its relationship to stand parameters and geomorphology features in the eastern Black sea region forests of Turkey. 
[17] Scholes, R. J. and Archer, S. R. (1997): Tree-grass interactions in savannas, Annual Review Ecological System, 28: 517-544

[18] Shannon, C. E., \& Weaver, W. (1949): The Mathematical theory of communication. Urbana, University Illinois Press.

[19] Spellerberg, I.F. (1991): monitoring Ecological change. New York USA, Cambridge University. 112140pp.

[20] SpiegeIberger T, Matthies D, Muller Sharer H, Schaffner U (2006): Scale dependent effects of land use on plant species richness of mountain grassland In the European Alps. Eco graphy 29:541-548.

[21] Sushma Singh, Zubair A. Malik,Chandra M. Sharma (2016): Tree species richness, diversity, and regeneration status indifferent oak (Quercusspp.) dominated forests of Garhwal Himalaya, India; Journal of Asia-Pacific Biodiversity, 9:293-300.

[22] Wunderle JM Jr. (1997): The role of animal seed dispersal in accelerating native forest regeneration on degraded tropical lands. Forest Ecology Management 99: 223-35.

Citation: J. Amonum et al., "Structure and Diversity of Tree Species at the College of Forestry and Fisheries, University of Agriculture Makurdi, Benue State, Nigeria", International Journal of Forestry and Horticulture (IJFH), vol. 5, no. 1, pp. 20-27, 2019. Available: DOI: http://dx.doi.org/10.20431/24549487.0501004

Copyright: (C) 2019 Authors. This is an open-access article distributed under the terms of the Creative Commons Attribution License, which permits unrestricted use, distribution, and reproduction in any medium, provided the original author and source are credited. 